\title{
Profiling the Importance of Fishing Trips of Saltwater Anglers: A Multinomial Logistic Regression Analysis
}

\author{
Yeong Nain Chi \\ Department of Agriculture, Food and Resource Sciences, University of Maryland Eastern Shore, Maryland
}

Copyright $(2016$ by authors, all rights reserved. Authors agree that this article remains permanently open access under the terms of the Creative Commons Attribution License 4.0 International License

\begin{abstract}
Using data collected from the 2013 National Saltwater Angler Survey, this study examined respondents' answers to fifteen statements regarding the importance of fishing trips to discern patterns from individuals' preferences, to classify groups exhibiting common patterns of responses, and to identify the determinants of respondent groups. These statements were condensed into five dimensions using the principal components analysis. Empirical results based on the two-stage cluster analysis identified three groups of respondents. A multinomial logistic regression analysis was utilized to examine the association between socio-demographic characteristics and cluster memberships. Results of this study may provide insight into the understanding of the importance of fishing trips among saltwater anglers for saltwater recreational fishing planning and management purposes.
\end{abstract}

Keywords Saltwater Anglers, The Importance of Fishing Trips, Factor Analysis, Cluster Analysis, Multinomial Logistic Regression Analysis

\section{Introduction}

Marine recreational fishing is a popular pastime across the United States that generates significant economic impacts to both local economies and to the United States. In February 2015, NOAA Fisheries released the National Saltwater Recreational Fisheries Policy, to provide guidance in pertaining to development and maintenance of enduring and sustainable high quality saltwater recreational fisheries, which recognized the importance of saltwater recreational fishing to the United States.

In 2011, over 70 million recreational fishing trips were taken by more than 11 million marine anglers in the United States. It is estimated that marine anglers spent an estimated $\$ 4.4$ billion on trip-based expenditures (e.g., ice, bait, and fuel) and another $\$ 19$ billion on fishing equipment and durable goods (e.g., fishing rods, fishing tackle, and boats) [10]. It is also shown that they contributed an estimated $\$ 56$ billion in total output impacts, $\$ 29$ billion in value-added impacts (i.e., contribution to gross domestic product), $\$ 18$ billion in income impacts, and supported 364 thousand jobs in the United States [10].

In addition, more than 33 million American fished in 2011. Among anglers, freshwater anglers numbered 27.5 million, while 8.9 million anglers participated in saltwater fishing. Anglers spent a total of $\$ 41.8$ billion, and sportspersons (including anglers and hunters) spent a total $\$ 14.3$ billion on items used for both hunting and fishing in 2011. Of the total fishing expenditures spent by anglers in 2011, anglers spent $\$ 21.8$ billion on trip-related costs, $\$ 15.5$ billion on fishing equipment, and $\$ 4.5$ billion on other fishing expenditures including land leasing and ownership, magazines and books, membership due and contributions, licenses, stamps, tags, and permits [15].

Among anglers, freshwater anglers spent more than \$25.7 billion, while saltwater anglers spent $\$ 10.3$ billion on their fishing trips and equipment in 2011. Of saltwater angler expenditures in 2011 , they spent a total of $\$ 7.3$ billion on trip-related costs -- $\$ 2.4$ billion on food and lodging, $\$ 1.5$ billion on transportation costs, and $\$ 3.4$ billion on other trip costs such as equipment rental, bait, and guide fees; and a total of $\$ 2.9$ billion on fishing equipment -- $\$ 1.4$ billion on equipment (rods, reels, etc.), \$217 million on auxiliary equipment (camping equipment, binoculars, etc.), and 1.3 billion on special equipment such as boats, vans, and so forth [15].

According to the 2001, 2006, and 2011 National Surveys of Fishing, Hunting, and Wildlife-Associated Recreation, the number of all anglers in the United States decreased from 34.1 million in 2001 to 30.0 million in 2006 , and increased to 33.1 million from 2006 to 2011 . Total fishing expenditures in 2011 dollars increased from 45.3 billion in 2001 to 47.0 billion in 2006, and decreased to 41.8 billion from 2006 to 2011. (U.S. Fish and Wildlife Service, 2014). The total number of saltwater anglers decreased from 9.5 million in 2001 to 7.7 million in 2006 , but increased to 8.9 million from 2006 to 2011. Total expenditures on saltwater fishing trip-related costs and equipment increased slightly from $\$ 8.4$ billion in 2001 to $\$ 8.9$ billion in 2006 , and also increased to 
\$10.3 billion from 2006 to 2011 [13] [14] [15].

A growing number of research studies has adopted market segmentation approach to analyze recreational anglers' fishing motivations [5] [3] [8] [1] [9]. No systematic study has been conducted related to understanding saltwater anglers from the importance of fishing trips perspective and specifically on profiling these groups of anglers using the multinomial logistic regression analysis approach. The purposes of this study are to examine respondents' answers to fifteen statements regarding the importance of fishing trips to discern patterns from individuals' preferences, to classify groups exhibiting common patterns of responses, and to identify the determinants of respondent groups. Results of this study may provide insight into the understanding of the importance of fishing trips among saltwater anglers for saltwater recreational fishing planning and management purposes. It may also contribute to a better understanding of current and future individual behavior of saltwater recreational fishing participation.

\section{Materials and Methods}

The data used in this study was extracted from the 2013 National Saltwater Angler Survey [2], which was developed by the NOAA Fisheries and collected by the CIC Research in 2013. The survey targeted saltwater anglers, 16 years of age and older who had been saltwater fishing at least once in their life, to elicit their participation, fishing preferences, and attitudes. The survey was implemented in six regions in the United States including North Atlantic, Mid-Atlantic, South Atlantic, Gulf of Mexico, West Coast, and Alaska.

Respondents were asked, "On most of your fishing trips, how important is it to ---", to indicate 15 statements regarding the importance of fishing trips, using a Likert-type scale that ranged from 1 (Not important at all) through 5 (Extremely important). This study examined the psychometric properties of the importance of fishing trips from the 7,812 saltwater anglers who provided complete information for all 15 statements (Table 1).

First, the dimensionality of the 15-item regarding the importance of fishing trips is assessed by examining the factor solution [6]. Specifically, the amount of variance explained by the extracted factors (i.e., their eigenvalues) is noted. In addition, item-factor correlations (i.e., factor loadings) and other indices of model adequacy are examined. A principal component analysis is used to determine the factors identified to the sample in this study. Second, a cluster analysis of respondents is conducted using a two-stage process to identify respondent groups exhibiting common patterns of responses. Third, a multinomial logistic regression analysis is employed to identify the determinants of respondent groups.

Table 1. Descriptive Statistics of the Importance of Fishing Trips

\begin{tabular}{|c|c|c|c|}
\hline On most of your fishing trips, how important is it to --- & Mean & S.D. & Communalities \\
\hline Catch fish & 4.14 & 0.859 & 0.506 \\
\hline Catch as many fish as I can for consumption & 2.99 & 1.290 & 0.706 \\
\hline Catch-and-release as many fish as possible & 3.15 & 1.217 & 0.668 \\
\hline Catch a trophy-sized fish & 3.04 & 1.290 & 0.642 \\
\hline Target a particular species & 3.33 & 1.188 & 0.521 \\
\hline Catch the bag limit of a species I am targeting & 2.77 & 1.302 & 0.700 \\
\hline Know that I will encounter abundant fish & 3.64 & 1.066 & 0.578 \\
\hline Fish in an area that is not heavily congested & 4.00 & 0.886 & 0.543 \\
\hline Be close to amenities & 2.95 & 1.295 & 0.574 \\
\hline See information concerning fishing regulations clearly posted & 3.62 & 1.274 & 0.681 \\
\hline Have access to staff to answer questions or provide information & 2.78 & 1.273 & 0.747 \\
\hline Have easy access to weather and tide information & 3.99 & 1.113 & 0.401 \\
\hline Fish in a scenic area & 3.28 & 1.153 & 0.517 \\
\hline Fish with family or friends & 4.33 & 0.843 & 0.717 \\
\hline Teach others about fishing & 3.75 & 1.067 & 0.704 \\
\hline
\end{tabular}

(Extremely important $=5$, Somewhat important $=4$, Neutral $=3$, Somewhat unimportant $=2$, Not important at all $=1$ ) 


\section{Results}

\subsection{Factor Analysis}

The original 15 -item regarding the importance of fishing trips is factor analyzed with varimax rotation, providing a clearer separation of the factors. As a result of the exploratory factor analysis, five factors are identified. The KMO measure of sampling adequacy was 0.747 , which meet the fundamental requirements for factor analysis. The Bartlett's test of Sphericity shows that nonzero correlations exist at the significance level of 0.001 (Table 2).

Each factor is named by examining the content of the variable making the greatest contribution to each of the dimensions. An initial interpretation of these factors suggests that Factor 1 named "Catch" factor comprises five items (structure coefficients ranging from 0.800 to 0.588 ) and explains 17.297 percent of the variance with an eigenvalue of 2.595. Factor 2 emphasized "Information" factor comprises four items (structure coefficients ranging from 0.853 to 0.511 ) and explains 15.420 percent of the variance with an eigenvalue of 2.313. Factor 3 focuses on "Site Preferences" factor comprises only two items (structure coefficients ranging from 0.716 to 0.660 ) and explains 9.587 percent of the variance with an eigenvalue of 1.438. Factor 4 focuses on "Social" factor comprises two items (structure coefficients ranging from 0.790 to 0.770 ) and explains 9.571 percent of the variance with an eigenvalue of 1.436. Factor 5 focuses on "Management" factor comprises two items as well (structure coefficients ranging from 0.771 to 0.665 ) and explains 9.483 percent of the variance with an eigenvalue of 1.423 .

The Cronbach's alpha is the most widely used measure of reliability which is an assessment of the degree of consistency between multiple measurements of a variable. The internal consistency coefficient score of the 15-item regarding the importance of fishing trips showed the Cronbach's alpha of 0.734 was acceptable, which explains a cumulative 61.358 percent of the variance in statement response (Table 2).

Table 2. Factor Analysis of the Importance of Fishing Trips

\begin{tabular}{|c|c|c|c|c|c|}
\hline On most of your fishing trips, how important is it to --- & Factor1 & Factor2 & Factor3 & Factor4 & Factor5 \\
\hline \multicolumn{6}{|l|}{ Factor 1: Catch } \\
\hline Catch the bag limit of a species I am targeting & 0.800 & & & & \\
\hline Catch as many fish as I can for consumption & 0.730 & & & & \\
\hline Catch fish & 0.634 & & & & \\
\hline Target a particular species & 0.618 & & & & \\
\hline Know that I will encounter abundant fish & 0.588 & & & & \\
\hline \multicolumn{6}{|l|}{ Factor 2: Information } \\
\hline Have access to staff to answer questions or provide information & & 0.853 & & & \\
\hline See information concerning fishing regulations clearly posted & & 0.814 & & & \\
\hline Be close to amenities & & 0.718 & & & \\
\hline Have easy access to weather and tide information & & 0.511 & & & \\
\hline \multicolumn{6}{|l|}{ Factor 3: Site Preferences } \\
\hline Fish in an area that is not heavily congested & & & 0.716 & & \\
\hline Fish in a scenic area & & & 0.660 & & \\
\hline \multicolumn{6}{|l|}{ Factor 4: Social } \\
\hline Fish with family or friends & & & & 0.790 & \\
\hline Teach others about fishing & & & & 0.770 & \\
\hline \multicolumn{6}{|l|}{ Factor 5: Management } \\
\hline Catch-and-release as many fish as possible & & & & & 0.771 \\
\hline Catch a trophy-sized fish & & & & & 0.665 \\
\hline Eigenvalue & 2.595 & 2.313 & 1.438 & 1.436 & 1.423 \\
\hline$\%$ of variance & 17.297 & 15.420 & 9.587 & 9.571 & 9.483 \\
\hline Cumulative \% & 17.297 & 32.717 & 42.304 & 51.875 & 61.358 \\
\hline \multicolumn{6}{|c|}{ Reliability Alpha Coefficient of All 15 Items $=0.734$} \\
\hline \multicolumn{6}{|c|}{ Kaiser-Meyer-Olkin (KMO) Measure of Sampling Adequacy $=0.747$} \\
\hline \multicolumn{6}{|c|}{ Bartlett's Test of Sphericity: Approx. Chi-Square $=25225.098 ; d f=105 ;$ Sig. $=0.000$} \\
\hline
\end{tabular}




\subsection{Cluster Analysis}

Cluster analysis techniques assign objects to groups so that there is as much similarity within groups, and difference between groups, as possible [4]. Factor scores of the importance of fishing trips dimensions are used to cluster saltwater anglers. Cluster analysis is applied as a two-stage process to the saved factor scores. In the first stage, Ward's hierarchical clustering method is employed to provide an indication of the appropriate number of clusters. In the second stage, the K-means clustering method is used to identify a solution with the specified number of clusters. Consequently a three-cluster solution is agreed upon. The clusters are labeled as "Catch and Social Environment", "Site Choice", and "Fishing Related" groups (Table 3).

Table 3. Cluster Analysis of the Importance of Fishing Trips

\begin{tabular}{|c|c|c|c|}
\hline & $\begin{array}{c}\text { Catch and } \\
\text { Social } \\
\text { Environment }\end{array}$ & Site Choice & $\begin{array}{c}\text { Fishing } \\
\text { Related }\end{array}$ \\
\hline Catch & 0.7493 & -0.9252 & -0.0188 \\
\hline Information & -0.0965 & 0.1130 & -0.0068 \\
\hline Site Preferences & -0.0448 & 0.3144 & -0.3707 \\
\hline Social & 0.3853 & 0.3612 & -1.2108 \\
\hline Management & -0.2277 & 0.0571 & 0.3272 \\
\hline $\mathrm{n}=7,812$ & 3317 & 2649 & 1846 \\
\hline Percentage & 42.5 & 33.9 & 23.6 \\
\hline
\end{tabular}

"Catch and Social Environment" cluster: this is the largest group comprising of approximately 42.5 percent of the respondents. These respondents are positively connected with "Catch" and "Social", but negatively identify with "Information", "Site Preferences" and "Management". "Site Choice" cluster: with 33.9 percent of the respondents, this group is named after the positively strong association with "Information", "Site Preferences", "Social" and "Management", but negatively identify with "Catch". "Fishing Related" cluster: this is the smallest group, comprising of approximately 23.6 percent of the respondents, named because of the positive factor score associated with "Management", negatively identify with "Catch", "Information", "Site Preferences" and "Social" among these respondents.

Results of the cluster analysis are tested for accuracy using the multiple discriminant analysis employed as a useful complement to cluster analysis, which is used primarily to predict membership in two or more mutually exclusive groups. In this case, the null hypothesis of equal population covariance matrices is rejected at $1 \%$ level of significance (the Box's $\mathrm{M}=1180.211 ; F=39.302 ; p=$ $0.000)$, and the Wilk's Lambda scores are $0.200\left(\chi^{2}=\right.$ 12582.739; $d f=10 ; p=0.000)$ and $0.471\left(\chi^{2}=5877.154 ; d f\right.$ $=4 ; p=0.000$ ) for both discriminant functions, respectively, indicating that group means are significantly different. The canonical correlation results are both above 0.7 , supporting that there are strong relationships between the discriminant score and the cluster membership (Table 4).

Table 4. Canonical Correlation of Discriminant Functions

\begin{tabular}{|c|c|c|c|}
\hline Function & Eigenvalue & $\begin{array}{c}\% \text { of } \\
\text { Variance }\end{array}$ & $\begin{array}{c}\text { Canonical } \\
\text { Correlation }\end{array}$ \\
\hline 1 & $1.361^{*}$ & 54.8 & 0.759 \\
\hline 2 & $1.123^{*}$ & 45.2 & 0.727 \\
\hline
\end{tabular}

* First 2 canonical discriminant functions were used in the analysis.

\subsection{Chi-Square Test and F Test}

Using the Chi-square test, the identified three groups demonstrated significant differences in gender composition $\left(\chi^{2}=34.469 ; d f=2 ; p=0.000\right)$ (Table 5). Similarly, the saltwater angler groups using the Chi-square test also demonstrated significant differences in income composition $\left(\chi^{2}=23.111 ; d f=14 ; p=0.058\right)$ at $10 \%$ level (Table 6$)$, insignificant differences in education composition $\left(\chi^{2}=\right.$ 11.283; $d f=8 ; p=0.186$ ) (Table 7), and significant differences in region composition $\left(\chi^{2}=195.693 ; d f=10 ; p=\right.$ 0.000) (Table 8).

Table 5. Gender Composition of the Saltwater Angler Clusters

\begin{tabular}{|c|c|c|c|c|}
\hline $\begin{array}{c}\text { Gender/ } \\
\text { Group }\end{array}$ & $\begin{array}{c}\text { Catch and Social } \\
\text { Environment }\end{array}$ & $\begin{array}{c}\text { Site } \\
\text { Choice }\end{array}$ & $\begin{array}{c}\text { Fishing } \\
\text { Related }\end{array}$ & Total \\
\hline Male & 2789 & 2134 & 1607 & 6530 \\
\hline Female & 528 & 515 & 239 & 1282 \\
\hline Total & 3317 & 2649 & 1846 & 7812 \\
\hline
\end{tabular}

Table 6. Income Composition of the Saltwater Angler Clusters

\begin{tabular}{|c|c|c|c|c|}
\hline $\begin{array}{c}\text { Income Level / } \\
\text { Group }\end{array}$ & $\begin{array}{c}\text { Catch and } \\
\text { Social } \\
\text { Environment }\end{array}$ & $\begin{array}{c}\text { Site } \\
\text { Choice }\end{array}$ & $\begin{array}{c}\text { Fishing } \\
\text { Related }\end{array}$ & Total \\
\hline Less than $\$ 20,000$ & 190 & 183 & 111 & 484 \\
\hline$\$ 20,000-\$ 39,999$ & 391 & 352 & 273 & 1016 \\
\hline$\$ 40,000-\$ 59,999$ & 523 & 447 & 298 & 1268 \\
\hline$\$ 60,000-\$ 79,999$ & 566 & 395 & 271 & 1232 \\
\hline$\$ 80,000-\$ 99,999$ & 502 & 373 & 287 & 1162 \\
\hline $\begin{array}{l}\$ 100,000- \\
\$ 149,999\end{array}$ & 641 & 507 & 350 & 1798 \\
\hline $\begin{array}{l}\$ 150,000- \\
\$ 199,999\end{array}$ & 234 & 189 & 126 & 549 \\
\hline$\$ 200,000$ or more & 270 & 203 & 130 & 603 \\
\hline Total & 3317 & 2649 & 1846 & 7812 \\
\hline
\end{tabular}


Table 7. Education Composition of the Saltwater Angler Clusters

\begin{tabular}{|c|c|c|c|c|}
\hline $\begin{array}{c}\text { Educational } \\
\text { Level / Group }\end{array}$ & $\begin{array}{c}\text { Catch and } \\
\text { Social } \\
\text { Environment }\end{array}$ & $\begin{array}{c}\text { Site } \\
\text { Choice }\end{array}$ & $\begin{array}{c}\text { Fishing } \\
\text { Related }\end{array}$ & Total \\
\hline $\begin{array}{c}\text { 12th Grade or } \\
\text { less }\end{array}$ & 242 & 196 & 146 & 584 \\
\hline $\begin{array}{c}\text { High school } \\
\text { graduate or GED }\end{array}$ & 777 & 606 & 440 & 1823 \\
\hline $\begin{array}{c}\text { Associate or } \\
\text { technical school } \\
\text { degree or college } \\
\text { coursework }\end{array}$ & 1031 & 751 & 551 & 2333 \\
\hline $\begin{array}{c}\text { Bachelor's } \\
\text { degree }\end{array}$ & 771 & 635 & 416 & 1822 \\
\hline $\begin{array}{c}\text { Advanced, } \\
\text { professional, or } \\
\text { doctoral degree } \\
\text { or coursework }\end{array}$ & 496 & 461 & 293 & 1250 \\
\hline Total & 3317 & 2649 & 1846 & 7812 \\
\hline
\end{tabular}

Table 8. Region Composition of the Saltwater Angler Clusters

\begin{tabular}{|c|c|c|c|c|}
\hline $\begin{array}{c}\text { Region / } \\
\text { Group }\end{array}$ & $\begin{array}{c}\text { Catch and } \\
\text { Social } \\
\text { Environment }\end{array}$ & $\begin{array}{c}\text { Site } \\
\text { Choice }\end{array}$ & $\begin{array}{c}\text { Fishing } \\
\text { Related }\end{array}$ & Total \\
\hline Alaska & 113 & 40 & 34 & 187 \\
\hline West Coast & 615 & 296 & 267 & 1178 \\
\hline North Atlantic & 344 & 423 & 322 & 1089 \\
\hline Mid-Atlantic & 693 & 610 & 448 & 1751 \\
\hline South Atlantic & 658 & 693 & 410 & 1761 \\
\hline $\begin{array}{c}\text { Gulf of } \\
\text { Mexico }\end{array}$ & 894 & 587 & 365 & 1846 \\
\hline Total & 3317 & 2649 & 1846 & 7812 \\
\hline
\end{tabular}

The one-way ANOVA results also showed that significant differences in age $(F(2,7809)=11.015, p=0.000)$ and years of fishing $(F(2,7809)=16.862, p=0.000)$ were found with the three groups identified (Table 9 ).

Table 9. Age and Years of Fishing Differences in the Saltwater Angler Clusters

\begin{tabular}{|c|c|c|c|c|}
\hline & & $d f$ & $F$ & $P$ \\
\hline \multirow{2}{*}{ Age } & $\begin{array}{c}\text { Between } \\
\text { Groups }\end{array}$ & 2 & 11.015 & 0.000 \\
\cline { 2 - 5 } & Within Groups & 7809 & & \\
\hline \multirow{2}{*}{$\begin{array}{c}\text { Years of } \\
\text { Fishing }\end{array}$} & $\begin{array}{c}\text { Between } \\
\text { Groups }\end{array}$ & 2 & 16.862 & 0.000 \\
\cline { 2 - 5 } & Within Groups & 7809 & & \\
\hline
\end{tabular}

\subsection{Multinomial Logistic Regression Analysis}

After the formation of the three groups, a multinomial logistic regression analysis (MLR) is utilized to examine the association between socio-demographic characteristics and cluster memberships. The MLR is useful for analyzing the effects of independent variables on a finite number of choices, appropriate to explain choices based on individual-specific data. It is actually an extension of the binary logit model, having more than two values for the dependent variable.
Adapted from Greene [7], an underlying consideration for the decision choices is based on a random utility model formalized for the $i^{\text {th }}$ individual facing $J$ choices, with the utility of choice $j$ being specified as follows:

$$
\mathrm{U}_{\mathrm{ij}}=\beta^{\prime} \mathrm{x}_{\mathrm{ij}}+\varepsilon_{\mathrm{ij}}
$$

where $\beta$ denotes the parameters to be estimated, $x$ is a vector of attributes corresponding to the state of choice $j$, and $\varepsilon$ is an error term. Suppose the $i^{\text {th }}$ individual selects choice $j$. Then we assume that $U_{i j}$ is the maximum among the $J$ utilities. The statistical model is then based on the probability that choice $j$ is made, which is expressed as follows:

$$
\text { Prob }\left(U_{i j}>U_{i k}\right) \text { for all other } k \neq j \text {. }
$$

Assume a distribution allows the model to be operationalized, and let $Y_{i}$ be a random variable indicating the choice made if and only if the $J$ disturbances are independent and identically distributed with Gumbel distribution [11]. Then

$$
\mathrm{F}\left(\varepsilon_{i j}\right)=\exp \left(-\exp \left(\varepsilon_{i j}\right)\right) \text { and }
$$

$\operatorname{Prob}\left(Y_{i}=j\right)=\exp \left(\beta^{\prime} x_{i j}\right) / \sum_{j} \exp \left(\beta^{\prime} x_{i j}\right) \quad$ for $\mathrm{j}=1,2,3, \ldots, \mathrm{J}$

The estimated equations provide a set of probabilities for the $J$ choices.

In the MLR, the independent variable can be explained based on the individual-specific explanatory variables for each cluster, so that a vector of estimated parameters results for each cluster. One way of interpreting the relationship between a predictor and the dependent variable is by computing predicted probabilities. The predicted probabilities for the $i^{\text {th }}$ individual to belong to the cluster $j$ can be calculated as,

$$
\operatorname{Prob}\left(Y_{i}=j\right)=\exp \left(\beta_{\mathrm{j}}{ }^{\prime} x_{i}\right) / \sum_{j} \exp \left(\beta_{\mathrm{j}}{ }^{\prime} x_{i}\right) \quad \text { for } \mathrm{j}=1,2,3
$$

where $Y_{i}$ is the dependent variable faced with the cluster $j, x_{\mathrm{i}}$ is the vector of the independent variables associated to the individual $i$, and $\beta_{\mathrm{j}}$ is the coefficient vector of parameters associated to the cluster $j$. The estimation is done by maximization of the likelihood function.

In this study, the dependent variable, the three respondent groups, can take the value $1=$ Catch and Social Environment cluster, 2 = Site Choice cluster, and $3=$ Fishing Related cluster. The explanatory variables considered in the model are years of fishing, age, gender, income level, educational level, region of the respondent. Empirically, the MLR in this study can be expressed as

$$
\begin{aligned}
& \log \frac{\operatorname{Prob}\left(Y_{i}=j\right)}{\operatorname{Prob}\left(Y_{i}=j^{\prime}\right)}= \\
& \left.\left.\left.=\alpha+\beta_{1} \text { (years of fishing }\right)+\beta_{2} \text { (age }\right)+\beta_{3} \text { (gender }\right)+\beta_{4}(\text { income })+ \\
& \beta_{5} \text { (education) }+\beta_{6} \text { (region) }
\end{aligned}
$$

where $j$ is the identified cluster, Catch and Social Environment cluster or Site Choice cluster, and $j$ ' is the reference cluster, Fishing Related cluster.

\subsection{Model Fit}


Most commonly way to assess model fit in the MLR is the likelihood ratio test. Here, the $-2 \log$ likelihood is computed for the intercept-only model, or the model without any independent variables, and the final model with all independent variables. The $-2 \log$ likelihoods for each are subtracted from one another to produce the Chi-square $(16738.587-16610.871=127.716)$, shown in Table 10. A greater amount of change between the two models suggests a greater improvement in model fit. Significance at less than 0.05 suggests model fit. Here, the final model is significantly different from the intercept-only model $(p<0.0001)$. Thus, the independent variables contribute significantly to prediction of the outcome. A lower Akaike's Information Criterion (AIC) for the final model compared to the intercept-only model also suggests good fit [12].

\subsection{Parameter Estimates for the Final Model}

Table 11 presents the parameter estimates for the final model. The "Fishing Related" cluster is the reference group. It is compared to the "Catch and Social Environment" cluster and the "Site Choice" cluster, with separate parameter estimates. This is one of the main strengths of MLR - different estimates are computed for all paired groupings of the dependent variable. This means that different effects of particular variables within each group can be identified.

It was found that "Catch and Social Environment" and the "Fishing Related" clusters were differentiated on four variables, including years of fishing and age at $1 \%$ level, gender and income level at 5\% level, but not educational level and region. For the variable "years of fishing", the log odds of a saltwater angler selecting "Catch and Social Environment" compared to "Fishing Related" increases by 0.0144 . This equates to an odds ratio of $1.011\left(\mathrm{e}^{0.0144}\right)$. From "years of fishing" perspective, saltwater anglers are more likely to choose "Catch and Social Environment". For the variable "gender", the $\log$ odds of a saltwater angler choosing "Catch and Social Environmental" compared to "Fishing Related" is 0.3035 , which equates to an odds ratio of $1.355\left(\mathrm{e}^{0.3035}\right)$. It appears that saltwater anglers are more likely to select "Catch and Social Environmental" than "Fishing Related" in terms of gender differences.

It was also found that "Site Choice" and the "Fishing Related" clusters were differentiated on four variables, such as age, gender and region at $1 \%$ level, and educational level at $10 \%$ level, but insignificant with years of fishing and income level. For the variable "age", the log odds of a saltwater angler selecting "Site Choice" as opposed to "Fishing Related" decreases by 0.0088 , which equates to an odds ratio of $0.991\left(\mathrm{e}^{0.0088}\right)$. From "age" perspective, saltwater anglers are less likely to choose "Site Choice". While this might appear to be a very small change in probability, age is a small measure and anglers' age may differ by large amounts. Similarly, for the variable "region", the log odds of a saltwater angler choosing "Site Choice" compared to "Fishing Related" is 0.0687 . This equates to an odds ratio of $1.071\left(\mathrm{e}^{0.0687}\right)$. Saltwater anglers are more likely to select "Site Choice" than "Fishing Related" associated with differences among regions.

Table 10. Model Fitting Information

\begin{tabular}{|c|c|c|c|c|c|c|}
\hline & \multicolumn{3}{|c|}{ Model Fitting Criteria } & \multicolumn{3}{c|}{ Likelihood Ratio Tests } \\
\hline Model & AIC & SC & -2 log Likelihood & Chi-square & $d f$ & Sig. \\
\hline Intercept only & 16742.587 & 16756.514 & 16738.587 & & & \\
\hline Final & 16638.871 & 16736.358 & 16610.871 & 127.716 & 12 & $<0.0001$ \\
\hline
\end{tabular}

Table 11. Parameter Estimates for the Final Model

\begin{tabular}{|c|c|c|c|c|c|c|c|}
\hline & \multirow[b]{2}{*}{$\beta$} & \multirow[b]{2}{*}{ Std. Error } & \multirow[b]{2}{*}{ Wald } & \multirow[b]{2}{*}{ Sig. } & \multirow[b]{2}{*}{ Odds Ratio } & \multicolumn{2}{|c|}{ 95\% Confidence Interval for Odds Ratio } \\
\hline & & & & & & Lower Bound & Upper Bound \\
\hline \multicolumn{8}{|c|}{ Catch and Social Environment Cluster } \\
\hline Intercept & 0.5277 & 0.2065 & 6.5283 & 0.0106 & & & \\
\hline Years of Fishing & 0.0114 & 0.0019 & 35.0757 & $<0.0001$ & 1.011 & 1.008 & 1.015 \\
\hline Age & -0.0146 & 0.0024 & 36.1336 & $<0.0001$ & 0.986 & 0.981 & 0.990 \\
\hline Gender & 0.3035 & 0.0863 & 12.3652 & 0.0004 & 1.355 & 1.144 & 1.604 \\
\hline Income & 0.0411 & 0.0165 & 6.1860 & 0.0129 & 1.042 & 1.009 & 1.076 \\
\hline Education & -0.0189 & 0.0273 & 0.4780 & 0.4893 & 0.981 & 0.930 & 1.035 \\
\hline Region & 0.0205 & 0.0203 & 1.0198 & 0.3126 & 1.021 & 0.981 & 1.062 \\
\hline \multicolumn{8}{|l|}{ Site Choice Cluster } \\
\hline Intercept & -0.1578 & 0.2145 & 0.5415 & 0.4618 & & & \\
\hline Years of Fishing & 0.0015 & 0.0020 & 0.6049 & 0.4367 & 1.002 & 0.998 & 1.005 \\
\hline Age & -0.0088 & 0.0025 & 12.6515 & 0.0004 & 0.991 & 0.986 & 0.996 \\
\hline Gender & 0.4408 & 0.0872 & 25.5560 & $<0.0001$ & 1.554 & 1.310 & 1.843 \\
\hline Income & 0.0018 & 0.0172 & 0.0106 & 0.9178 & 1.002 & 0.969 & 1.036 \\
\hline Education & 0.0518 & 0.0285 & 3.3018 & 0.0692 & 1.053 & 0.996 & 1.114 \\
\hline Region & 0.0687 & 0.0212 & 10.4836 & 0.0012 & 1.071 & 1.027 & 1.117 \\
\hline
\end{tabular}

* The Reference Category: Fishing Related Cluster 


\section{Discussion and Conclusions}

Identification of saltwater angler motivations for fishing is important because it helps saltwater recreational fisheries managers understand why people fish and why they choose a particular environment to fish. By identifying saltwater angler motivations, saltwater recreational fisheries managers can better understand the experiences desired by saltwater anglers.

This study suggests that the saltwater anglers' motivations - the importance of fishing trips - may be important in distinguishing different segments within the angling population. This study suggested that the 15 statements regarding the importance of fishing trips of U.S. saltwater anglers could be condensed into five attitudinal dimensions (Catch, Information, Site Preferences, Social, Management) using principal components analysis and performed a three-cluster solution, including Catch and Social Environment, Site Choice, and Fishing Related groups, using two-stage cluster analysis.

Catch and Social Environment angler cluster was the most common cluster of U.S. saltwater anglers, comprising $42.5 \%$ of the survey sample. They were more likely than their counterparts in the Site Choice and Fishing Related angler clusters to view the experiential and social components of their fishing experience as very or extremely important. In contrast, they placed less importance on information, site preferences, and other more traditional aspects of saltwater recreational fisheries management.

The customary objectives of saltwater recreational fisheries managers, fish size and populations, are not the primary attractants for all anglers. Indeed, Site Choice angler cluster, who comprised about $34 \%$ of the sample, place a relatively low priority on catching fish. To appeal to this segment, saltwater recreational fisheries managers should work to enhance the perceived environmental quality of fishing sites and to provide facilities and information that enhance the convenience and relaxation of the angling experience.

At the same time, the traditional saltwater recreational fisheries management goals are justified by their importance to the Management angler cluster. They are more likely to make a significant contribution to fish size and populations in which their angling activity takes place. To retain this important angler group, saltwater recreational fisheries managers should continue to pursue the traditional saltwater recreational fisheries management goals that enhance catch success.

The primary reasons for fishing for all saltwater anglers are to relax and enjoy the outdoors. Catching fish to eat or catching trophy fish are less important overall, but, to certain segments of anglers, these are very important reasons for fishing. Developing saltwater fisheries in natural settings, reducing crowding, and reducing user conflict will help the saltwater recreational fisheries managers provide fishing opportunities in which saltwater anglers can enjoy the outdoors and relax. Subgroups of saltwater anglers do place a great deal of importance on the catch aspects of fishing. Recognition of those subgroups and providing the experiences that they desire (trophy fish and consuming fish) should help improve saltwater angler satisfaction.

These results illustrate the diversity of saltwater anglers' motivations and belie the concept of an "average" angler. Saltwater recreational fisheries managers should be aware of this diversity when considering management options and striving to serve the entire angling public. There is room for expansion into several different markets. For example, marketing the naturalistic values of fishing may increase fishing participation among residents of urban areas. Marketing of the social (family and friends) and relaxation aspects of the fishery may help increase participation among these groups as well. Management should reach out to women and minorities to increase participation and environmental awareness among these groups.

Without information to identify saltwater angler motivations that influence saltwater recreational fishing participation among different angler segments, it is difficult to successfully attract diverse angler markets associated with their motivations and interests. Therefore, the success of the saltwater recreational fisheries programs and management strategies should consider the information of understanding saltwater angler motivations. Saltwater recreational fisheries managers should address the desires and needs of each segment when developing saltwater recreational fisheries management plans. By providing opportunities for each segment, saltwater recreational fisheries management should be more effective and efficient and saltwater angler satisfaction and participation may increase. However saltwater recreational fisheries managers should be aware that providing the desired experiences of one segment may come at the expense of other segments. If possible, saltwater recreational fisheries managers should find a balance of opportunities for each segment and be careful not to exclude segments of saltwater anglers.

\section{Acknowledgements}

The author would like to thank Dr. Ayeisha A. Brinson and Dr. Kristy Wallmo of NOAA Fisheries Service for providing the data necessary to accomplish this study.

\section{REFERENCES}

[1] Ardahan, F. 2012. Reliability and validity of recreational fishing motivations scale in Turkish population. Turkish Journal of Sport and Exercise, 14(3): 59-65.

[2] Brinson, A.A. and Wallmo, K. 2013. Attitudes and preferences of salter recreational anglers: Report from the 2013 National Saltwater Angler Survey, Volume I. U.S. Department of Commerce, NOAA Technical Memorandum NMFS-F/SPO$135,45 p$. 
[3] Chi, Y.N. 2006. Segmenting fishing markets using motivations. E-Review of Tourism Research, 4(3): 64-73.

[4] Churchill, G.A., Jr. and Iacobucci, D. 2005. Marketing research: methodological foundations, Ninth edition. Mason, $\mathrm{OH}$ : Thomson/South-Western.

[5] Connelly, N.A., Brown, T.L. and Knuth, B.A. (2000). A multiple market segmentation of Great Lakes anglers in New York. North American Journal of Fisheries Management, 20: 399-407.

[6] Gerbing, D. W. and Anderson, J.C. 1988. An updated paradigm for scale development incorporating unidimensionality and its assessment. Journal of Marketing Research, 25: 186-192.

[7] Greene, W.H. 2008. Econometric analysis, Sixth edition. Upper Saddle River, NJ: Prentice Hall.

[8] Hunt, K. M., Hutt, C. P., Grado, S.C., Neal, J. W. and Mischke, C.C. 2010. Market segmentation of potential fee-fishing participants in Mississippi and their willingness to pay for fishing on private waters. Human Dimension \& Conservation Law Enforcement Laboratory Technical Document \#145, Forest \& Wildlife Research Center, Mississippi State University.

[9] Kuehn, D., Durante, G., Brincka, M., Luzadis, V. and MacNeill, D. 2013. Lake Ontario resident anglers:
Motivations, constraints, and facilitators. New York Sea Grant, NYSGI-S-13-001, 21 p. Retrieved August 2016 from http://www.esf.edu/for/kuehn/documents/Residentanglerrepo rt8-8-13.pdf

[10] Lovell, S., Stenback, S. and Hilger, J. 2013. The economic contribution of marine angler expenditures in the United States, 2011. U.S. Department of Commerce, NOAA Technical Memorandum NMFS-F/SPO-134, 188 p.

[11] McFadden, D. 1974. Conditional logit analysis of qualitative choice behavior. In P. Zarembka, ed., Frontiers in econometrics. New York: Academic Press.

[12] Tabatchnich, B. G. and Fidell, L.S. 2007. Using multivariate statistics, Fifth edition. Boston: Pearson Education, Inc.

[13] U.S. Department of the Interior, U.S. Fish and Wildlife Service, \& U.S. Department of Commerce, U.S. Census Bureau. 2002. 2001 National Survey of Fishing, Hunting, and Wildife-Associated Recreation.

[14] U.S. Department of the Interior, U.S. Fish and Wildlife Service, \& U.S. Department of Commerce, U.S. Census Bureau. 2007. 2006 National Survey of Fishing, Hunting, and Wildlife-Associated Recreation.

[15] U.S. Department of the Interior, U.S. Fish and Wildlife Service, \& U.S. Department of Commerce, U.S. Census Bureau. 2014. 2011 National Survey of Fishing, Hunting, and Wildife-Associated Recreation. 